\title{
PASTURE RENOVATION IN THE SOUTH ISLAND HILL COUNTRY USING CONSERVATION TILLAGE
}

M.J. WILLOCKS and P.M. DESBOROUGH
Monsanto (NZ) Ltd, Christchurch

\begin{abstract}
Pasture renovation using Conservation Tillage including herbicide is a fast, efficient method of improving low producing pastures. The advent of Glyphosate has enabled pastures to be renovated without the need for a break-crop and thus minimal loss of production. Because of the rapid and substantial increase in carrying capacity, the cost of renovation can be recovered within 1-2 years of sowing.

For these reasons pasture renovation using Conservation Tillage is becoming accepted practice in the hill and high country.
\end{abstract}

Keywords: Pasture renovation, conservation tillage, hill country, glyphosate.

\section{INTRODUCTION}

Approximately 500,000 hectares of South Island hill and high country pastures are dominated by browntop (Agrostis capillaris), Poa pratensis and annual grasses. Production is limited due to the short growing season of these species and low palatability. Improvement of this country is time consuming, expensive and often difficult due to terrain and the need to adequately break down the turf mat. This required that some form of forage crop must be incorporated into the rotation with the result that it is often 18 months from the start of a cultivation programme until the final sowing down of pasture. During this time the soil is prone to erosion from wind and water, with potentially damaging consequences.

This paper describes the technique of pasture renovation using Conservation Tillage, negating the need for long and expensive cultivation programmes, providing a fast and efficient technique of pasture establishment.

\section{THE TECHNIQUE OF CONSERVATION TILLAGE}

Conservation Tillage is the general term for a crop or pasture establishment system, where cultivation is replaced or reduced by the use of a herbicide.

From experience gained through trial work and farmer adoption (Desborough 1984), it has been shown that best results are achieved if the following guidelines are followed:

\section{Soll Fertility}

Ideally a pH in the region of $6,0-6.5$ should be aimed for. Early soil testing is recommended so that the $\mathrm{pH}$ can be adjusted if necessary. Lime should be applied at least 6 months prior to planting for optimum results.

\section{Preparation of the Pasture for Spraying}

Removal of seedheads and trash prior to spraying, by burning or heavy grazing is important to ensure access of glyphosate (Roundup@) to actively growing plants. Trash removal is usually carried out during the winter prior to planting. 


\section{Herbicide Application}

Following trash removal the pasture is allow to regrow to $5-10 \mathrm{~cm}$ prior to the application of glyphosate at $\mathbf{0 . 5 \cdot 1 . 0 8}$ ai/ha, in time with the onset of spring growth. It can be carried out right up to the planned planting date.

\section{Post-Spray Management}

If required, grazing may start from five days after treatment. This period allows for complete translocation of the glyphosate within the plant.

Drilling of superior pasture species can take place immediately after the spray has dried, provided a coulter system on the drill is used that creates minimal sward disturbance. However, where browntop infestation is dense, improved results have been achieved if the time between spraying and drilling is extended to 14-21 days. If resident clover populations are low, the practice has been to emphasize the clover seeding rate, at the expense of the grass rate. Seed blend varies with area, depending upon altitude and climate, but in general is similar to that used for pasture establishment using cultivation.

\section{Grazing Management}

Depending upon climatic conditions, the first light grazing can take place 6-8 weeks after planting, and normal grazing practised 10-12 weeks post planting.

\section{DISCUSSION}

The use of glyphosate effectively controls resident grasses and broadleaf species with the result that improved pasture can be sown directly into a herbicide treated sward without the need for a break-crop to aid turf mat break down and seed bed preparation (Frengley 1983). Under a cultivation regime, the area of pasture that could be renovated is limited to the amount of break-crop that could be utilized and the area of land that could be out of a pastoral situation for up to 18 months. With an average period of $\mathbf{8}$ weeks between drilling new pasture and initial grazlng, land is not out of production for a long period, therefore pasture can be renovated when it is deemed necessary and larger areas can be renovated in any season.

Farmer experience indicates an increase in carrying capacity of up to 6.8 stock units per hectare. With these increases the cost of renovation is recovered in 12-24 months, which is a similar period required for sowing down a pasture under a conventional cultivation regime.

\section{REFERENCES}

Desborough, P.M. 1984. Proc. Monsanto Conservation Tillage Sem.

Frengley, G.A.G. 1983. Economics and Management N.Z. Agric. Sc. 17: No. 3. 